\section{(2) \\ Check for updates}

Article Type: Research Paper

\title{
RAMADHAN, EID UL FITR, AND INFLATION: LESSON FROM INDONESIAN SUBNATIONAL DATA
}

\author{
Samsubar Saleh ${ }^{1}$, Dyah Titis Kusuma Wardani ${ }^{2,4}$, and Madha Adi Ivantri ${ }^{3 *}$
}

\begin{abstract}
Inflation has always been being seen as one of the most important macroeconomic variables in modern economies. Every year, media especially in Muslim countries has constantly reported that inflation rates increase during the Islamic holy month of Ramadhan and Eid UI Fitr. Remarkably, there has been hitherto almost no serious study focusing on the empirical relationship between Ramadhan, Eid UI Fitr and inflation. This research aims to examine empirically whether Ramadhan and Eid UI Fitr have a systematic effect on inflation. This research uses regression analysis technique and involves data from 66 local economies in Indonesia between January 2000 and December 2017. The finding of this paper is Ramadhan and Eid UI Fitr have a positive effect on inflation. The possible reasons for explaining the results is the high of public demand. To overcome inflation in Indonesia not only from the role of government in controlling inflation rate, but also the role of Muslims community in controlling consumption.
\end{abstract}

Keywords: Ramadhan; Eid UI Fitr; Inflation; Indonesia; Local Economies.

JEL Classification: B55; E00; E31; R20; Z12.

\section{*CORRESPONDENCE:}

madha_adi@yahoo.com

THIS ARTICLE IS AVALILABLE IN:

http://journal.umy.ac.id/index.php/esp

DOI: $10.18196 /$ jesp.20.2.5020

\section{CITATION:}

Saleh, S., Wardani, D. T. K., \& Ivantri, M. A. (2019). Ramadhan, Eid UI Fitr, and Inflation: Lesson From Indonesian Subnational Data. Jurnal Ekonomi \& Studi Pembangunan, 20(2), 135-150.

\section{ARTICLE HISTORY}

Received:

30 June 2019

Accepted:

22 October 2019

\section{Introduction}

Inflation has always been being seen as one of the most important macroeconomic variables in modern economies. It is this variable that will possibly weaken or even damage decades of economic growth if unleashed and not curbed (Barro, 1995; Gregorio, 1992; Vinayagathasan, 2013; Bittencourt, 2012; Hung, 2003). It is this variable that is concerned by central bankers globally and forces them to take monetary policies that are not always popular.

Every year, media especially in Muslim countries has constantly reported that inflation rates increase during the Islamic holy month of Ramadhan and Eid UI Fitr. Many reports have also acknowledged the persistent increase of inflation rate in the months within which Ramadhan and Eid UI Fitr fall (FAO, 2010; The World Bank, 2013). Given that Ramadhan and Eid Ul Fitr fall in different month in different years, they cannot simply be treated as seasonal adjustment measure like Christmas or Solar New Year. 
Understanding the effect that Ramadhan and Eid UI Fitr may possibly have on inflation is therefore very important, not only for the making of appropriate monetary policies but also the making of business decisions.

Economic analyses on inflation are hardly new (Laidler \& Parkin, 1975). There have been a bulk of works examining the cause and consequences on inflation using both theoretical (Saad-Filho 2000; Fuhrer, Kodrzycki, Little, Olivei, \& Samuelson, 2009) and empirical approaches (Gali \& Gertler, 1999; Orphanides, 2002; Kaihatsu \& Nakajima, 2018; Montes \& da Cunha, 2018; Xu, Chang, Lobont \& Su, 2016). However, the dependence of inflation on Ramadhan and Eid UI Fitr seems to be missed.

There are at least two mechanisms through which Ramadhan and Eid UI Fitr may affect inflation. The first is changes in aggregate demand. During Ramadhan, muslims are discouraged from consumption. If Muslims do follow what Islam teaches, aggregate demand should decrease. However, Muslims behavior do not necessarily follow what Islam teaches.

Besides, Ramadhan is also the month of charity. It is in this month that the best charity is to be given, mostly to support the poor and the needy. Since the MPC is higher in the case of poor and ordinary people than it is for the extremely wealthy, the transfer of income from the wealthy to the poor may thus increases aggregate demand.

The second mechanism through which Ramadhan and Eid UI Fitr may affect inflation is changes in the aggregate supply. During daylight hours, muslims cannot eat nor drink. People stay up late to break their fast and get up in the early morning hours so they can eat before daybreak. This results in shorter sleeping hours which can cause people to become more lethargic later on in the day. Consequently, the productivity of workers may decline as the workers are less fit than normal. The employers decide to transfer the increased wages into prices, which triggers inflation. This is consistent with the Keynesian explanation of inflation.

The third mechanism through which Ramadhan and Eid UI Fitr may affect inflation is changes in people's expectations about future inflation. Expected inflation is among the factors important for wage formation (Goretti, 2008; Holland, 1984; Nickell \& Quintini, 2003). Employees expecting higher inflation may require higher wages to compensate for their higher cost of living. Firms, in order to uphold profit margins, may in turn shift the higher costs of labor onto consumers. Higher consumer prices may further induce more demands for higher nominal wages, leading to a self-sustaining upward trend in price levels.

Expected inflation is also important for investment decision (Huizinga, 1993; Mills, 1996). Firms expecting higher inflation may anticipate that consumer demand will decrease, while costs of inputs will increase. Besides, firms expecting higher inflation may anticipate that the central bank's reference interest rates will rise to deal with inflation. These induce the firms to set lower revenue and selling targets and further delay their production and investment plans, leading to potential supply shocks. 
It should be noted that more intense levels of competition in the labor markets and in the markets for goods and services may help reduce the risk of a wage price spiral. For example, Holz \& Mehrotra (2013) recently find that, in China, firms do not fully pass through increases in labor costs to consumer prices, in both the tradable goods sector and in the economy as a whole.

Finally, a credible monetary policy may help reduce expected price and reduce the inflationary effect of government-set fuel price changes (Perrier \& Amano, 2000). By credible it means that the central bank and the government in general are believed to actually carry out their stated plans. If the monetary policy taken to accompany changes in government-set fuel prices is credible, inflation uncertainty should be less pronounced.

Remarkably, there has been hitherto almost no serious study focusing on the empirical relationship between Ramadhan, Eid UI Fitr and inflation. So, this study contributes to the exiting literature by determining the relationship between Ramadhan, Eid UI Fitr and inflation by two aspects: Firstly, few scientific papers treat these events are at best placed as control variables for other variables of interest (Grigorian \& Kock, 2010). Secondly, no scientific papers treat this relationship in Indonesia. Finally, we analyze this relationship in Indonesia on the grounds that Indonesia is the largest Muslim population in the world and has a level of religiosity in the country of $99 \%$, which indicates that religion plays an important role in daily life and society (Crabtree, 2010).

Our research have limitations, which also serve to highlight future research opportunities. We acknowledge that our empirical data do not go beyond what the direct observation were able to articulate and we were able to interpret. For example, we didn't observe the lack distribution of good as inflation determinant. Furthermore, we only observe the selected variables with consideration of data availability. We tried to minimize these limitations by control variables, which is influence of inflation.

\section{Research Method}

We use Panel Least Square method to investigate the effect of Ramadhan and Eid UI Fitr on inflation. According to Baltagi (2005), there are three approaches that can be used to estimate panel data, such as Pooled ordinary Least Square (PLS, fixed effect (FE), and random effect (RE) model. We use Chow test, Hausman test, and Lagrange Multiplier test to choose the most appropriate model. However, to make sure that the conclusion drawn is not due to the choice of estimation model, the regressions in this research are also reestimated using another model to compare (We using FE in this research). The regression equation is provided by:

$$
\Delta P_{i, t}=\beta_{0}+\beta_{1} R_{t}+\beta_{2} E_{t}+\beta_{3} X_{t}+\beta_{3} Z_{i, t}+\epsilon_{i, t}
$$

where the dependent variable, $\Delta P$, is a month-to-month local inflation rate and the key independent variables, $R$ and $E$, are dummies for Ramadhan and for Eid UI Fitr 
respectively. The binary variable for Ramadhan takes the value one for every month within which Ramadhan begins and zero otherwise. Similarly, the binary variable for Eid $\mathrm{UI}$ Fitr takes the value one for all the months within which Eid UI Fitr takes place and zero otherwise.

The Roman letters, $X$ and $Z$, denote two vectors of control variables. The former includes control variables whose values are shared to all cities in period $t$, namely the percent change in international oil prices, the percent change in international food prices, IDR per US\$ exchange rate, broad money (M2) supply, and dummies for the start of Ramadhan and the Eid UI Fitr day. By contrast, the later includes a control variable whose values are specific to each city in period $t$, namely the percent change in local minimum wage.

Data for the beginning of Ramadhan and Eid UI Fitr are collected from various resources. Data for international oil prices are approximated using Europe Brent Spot Prices (FOB) published by the United States' Energy Information Administration (EIA), while international food prices are approximated using the Food and Agriculture Organization (FAO)'s food price index. Data for the IDR per US\$ exchange rate and broad money (M2) supply are taken from Bank Indonesia, while information on fuel price increases and fuel price decreases are collected from various sources, especially the website of the Ministry of Energy and Mineral Resources.

In this research we uses panel data observations from 66 local economies in Indonesia between January 2000 and December 2017. The selection of sample cities is driven largely by data availability. A growing body of the panel data literature concludes that panel data models are likely to exhibit substantial cross-sectional dependence in the errors (De Hoyos and Sarafidis, 2006). Pesaran developed test to check Cross-sectional Dependence (CD). The null hypothesis of $C D$ test states that there exist no $C D$ among sample countries. The alternative hypothesis states there exist CD among sample countries (Pesaran, 2004; 2007).

\section{Result and Discussion}

\section{Basic Result for The Relationship of Ramadhan and Eid UI Fitr on Inflation}

In this section, we report basic regression results the relationship between Ramadhan and Eid UI Fitr to inflation. Based on the panel data test (Chow Test, Lagrange Multiplier Test, and Hausman Test) we found that the best estimator for regression model is Pooled ordinary Least Square PLS (See Appendix B.1; B.2; dan B.3). The regression output of PLS is as Table 1. In column 1, the regression includes only an intercept the dummy for the start of Ramadhan and dummy for the Eid UI Fitr day. The coefficient of Ramadhan and Eid UI Fitr day are all positive and significantly different from zero at the $1 \%$ level. In column 2, other independent variables are added, the coefficients of the dummies for the start of Ramadhan and the Eid UI Fitr day are all remains unchanged. The estimates in column 2 indicate that, holding other variables constant, local inflation rates in Indonesia 
will be 0.846 percent higher in the months of Ramadhan fall than in other months. The estimates in column 2 also indicate that, assuming no change in other regression, local inflation rates will be 0.576 percent higher in the months of Eid UI Fitr fall than in other months. In columns 3, we add the dummy for gasoline price increase and for gasoline price decrease. Again, our coefficient of interest, namely the start of Ramadhan and the Eid UI Fitr day the remains positive and significant at the $1 \%$ level. In addition, we find that local inflation rates in Indonesia will be higher in the months with gasoline price increase than in other months with no gasoline price increase.

In columns 4-6, we regress dummy for the start of Ramadhan and for the Eid UI Fitr day with alternative designation, where takes the value of 1 in the succeeding months if the first day of Ramadhan took place within the final week and the same procedure for Eid UI Fitr (the difference between basic and alternative designation see Appendix A). We find that the coefficient of the dummies for Ramadhan and for the Eid UI Fitr day remain significant at the 1 percent level. This result indicates that the relationship between Ramadhan and Eid UI Fitr and inflation is persistent.

Meanwhile, estimates using the Fixed Effect Model (FEM) indicate a cross-sectional dependency problem (see appendix B.4), so we use PCSE estimates for robust results. Table 2 shows the results from estimating using panel-corrected standard error (PCSE). The coefficient of Ramadhan and Eid UI Fitr day are positive and significant in all specifications at the $1 \%$ and $5 \%$ level. In terms of interpretation, using column 2 , we find that local inflation rates in Indonesia will be 0.963 percent higher in the months of Ramadhan fall than in other months. The estimates in column 2 also indicate that local inflation rates will be 0.532 percent higher in the months of Eid UI Fitr fall than in other months.

According to the result PLS and PCSE estimator, the value of R square on all models have a low value, its mean variables outside the model have a greater influence on dependent variables. Using table 1 column 2 , the value of $R$ square from PLS estimator are 8.5 percent, meaning that variance in the independent variables can explain by 8.5 percent on the variance local inflation in Indonesia. Meanwhile, using table 2 column 2, the value of $\mathrm{R}$ square from PCSE estimator are 8.6 percent, meaning that variance in the independent variables can explain by 8 percent on the variance local inflation in Indonesia. However, the findings from both the PLS and PCSE estimators are broadly consistent and confirm the finding in line with our theoretical model that Ramadhan and Eid UI Fitr matters for inflation or in other word the month of Ramadhan and Eid UI Fitr increases local inflation in Indonesia. 
Saleh, Wardani, \& Ivantri

Ramadhan, Eid UI Fitr, and Inflation: Lesson from Indonesian Subnational Data

Table 1 Ramadhan, Eid UI Fitr, and Inflation: The Basic Results using PLS

\begin{tabular}{|c|c|c|c|c|c|c|}
\hline \multirow{3}{*}{ VARIABLES } & \multicolumn{6}{|c|}{ Pooled Least Squares (PLS) } \\
\hline & (1) & (2) & (3) & (4) & (5) & (6) \\
\hline & Inflation & Inflation & Inflation & Inflation & Inflation & Inflation \\
\hline $\begin{array}{l}\text { Dummy for the } \\
\text { start of } \\
\text { Ramadhan }\end{array}$ & $\begin{array}{l}0.865^{* * *} \\
(0.03)\end{array}$ & $\begin{array}{l}0.846^{* * *} \\
(0.04)\end{array}$ & $\begin{array}{l}0.872 * * * \\
(0.04)\end{array}$ & & & \\
\hline $\begin{array}{l}\text { Dummy for the } \\
\text { Eid UI Fitr day }\end{array}$ & $\begin{array}{l}0.540 * * * \\
(0.03)\end{array}$ & $\begin{array}{l}0.551^{* * *} \\
(0.03)\end{array}$ & $\begin{array}{l}0.576 * * * \\
(0.03)\end{array}$ & & & \\
\hline $\begin{array}{l}\text { Dummy for the } \\
\text { start of } \\
\text { Ramadhan } \\
\text { (alternative) }\end{array}$ & & & & $\begin{array}{l}1.026 * * * \\
(0.03)\end{array}$ & $\begin{array}{l}1.018^{* * *} \\
(0.04)\end{array}$ & $\begin{array}{l}1.053^{* * *} \\
(0.04)\end{array}$ \\
\hline $\begin{array}{l}\text { Dummy for the } \\
\text { Eid UI Fitr day } \\
\text { (alternative) }\end{array}$ & & & & $\begin{array}{l}0.373^{* * *} \\
(0.03)\end{array}$ & $\begin{array}{l}0.381^{* * *} \\
(0.03)\end{array}$ & $\begin{array}{l}0.416 * * * \\
(0.03)\end{array}$ \\
\hline $\begin{array}{l}\text { Percent increase } \\
\text { in minimum wage }\end{array}$ & & $\begin{array}{l}-0.000 \\
(0.00)\end{array}$ & $\begin{array}{l}-0.000 \\
(0.00)\end{array}$ & & $\begin{array}{l}-0.000 \\
(0.00)\end{array}$ & $\begin{array}{l}-0.000 \\
(0.00)\end{array}$ \\
\hline $\begin{array}{l}\text { Broad money } \\
\text { (M2) supply }\end{array}$ & & $\begin{array}{l}0.000 * * * \\
(0.00)\end{array}$ & $\begin{array}{l}0.000^{* *} \\
(0.00)\end{array}$ & & $\begin{array}{l}0.000 * * * \\
(0.00)\end{array}$ & $\begin{array}{l}0.000 * \\
(0.00)\end{array}$ \\
\hline $\begin{array}{l}\text { IDR per US\$ } \\
\text { exchange rate }\end{array}$ & & $\begin{array}{l}0.000 * * * \\
(0.00)\end{array}$ & $\begin{array}{l}-0.000 * * * \\
(0.00)\end{array}$ & & $\begin{array}{l}0.000 * * * \\
(0.00)\end{array}$ & $\begin{array}{l}0.000 * * * \\
(0.00)\end{array}$ \\
\hline $\begin{array}{l}\text { Percent change in } \\
\text { int'l food price }\end{array}$ & & $\begin{array}{l}- \\
0.006^{* * *} \\
(0.00)\end{array}$ & $\begin{array}{l}-0.005^{* * *} \\
(0.00)\end{array}$ & & $\begin{array}{l}- \\
0.006^{* * *} \\
(0.00)\end{array}$ & $\begin{array}{l}- \\
0.005^{* * *} \\
(0.00)\end{array}$ \\
\hline $\begin{array}{l}\text { Percent change in } \\
\text { int'l oil price }\end{array}$ & & $\begin{array}{l}0.008^{* * *} \\
(0.00)\end{array}$ & $\begin{array}{l}0.007^{* * *} \\
(0.00)\end{array}$ & & $\begin{array}{l}0.008^{* * *} \\
(0.00)\end{array}$ & $\begin{array}{l}0.007 * * * \\
(0.00)\end{array}$ \\
\hline $\begin{array}{l}\text { Dummy for } \\
\text { gasoline price } \\
\text { increase }\end{array}$ & & & $\begin{array}{l}0.437 * * * \\
(0.04)\end{array}$ & & & \\
\hline $\begin{array}{l}\text { Dummy for } \\
\text { gasoline price } \\
\text { decrease }\end{array}$ & & & $\begin{array}{l}-0.087 \\
(0.08)\end{array}$ & & & \\
\hline $\begin{array}{l}\text { Dummy for } \\
\text { gasoline price } \\
\text { increase } \\
\text { (alternative) }\end{array}$ & & & & & & $\begin{array}{l}0.591 * * * \\
(0.04)\end{array}$ \\
\hline $\begin{array}{l}\text { Dummy for } \\
\text { gasoline price } \\
\text { decrease } \\
\text { (alternative) }\end{array}$ & & & & & & $\begin{array}{l}-0.075 \\
(0.08)\end{array}$ \\
\hline Observations & 11,928 & 10,942 & 10,942 & 11,928 & 10,942 & 10,942 \\
\hline R-squared & 0.071 & 0.085 & 0.093 & 0.080 & 0.095 & 0.110 \\
\hline Standard errors i & rentheses & & & & & \\
\hline$* * * \mathrm{p}<0.01, * * \mathrm{p}<$ & $5, * p<0.1$ & & & & & \\
\hline
\end{tabular}


Saleh, Wardani, \& Ivantri

Ramadhan, Eid UI Fitr, and Inflation: Lesson from Indonesian Subnational Data

Table 2 Ramadhan, Eid UI Fitr, and Inflation: Re-estimated using PCSE

\begin{tabular}{|c|c|c|c|c|c|c|}
\hline \multirow{3}{*}{ VARIABLES } & \multicolumn{6}{|c|}{ Panel-Corrected Standard Error (PCSE) } \\
\hline & (1) & (2) & (3) & (4) & (5) & (6) \\
\hline & Inflation & Inflation & Inflation & Inflation & Inflation & Inflation \\
\hline $\begin{array}{l}\text { Dummy for the start } \\
\text { of Ramadhan }\end{array}$ & $\begin{array}{l}0.973^{* * *} \\
(0.17)\end{array}$ & $\begin{array}{l}0.963^{* * *} \\
(0.18)\end{array}$ & $\begin{array}{l}0.985^{* * *} \\
(0.18)\end{array}$ & & & \\
\hline $\begin{array}{l}\text { Dummy for the Eid UI } \\
\text { Fitr day }\end{array}$ & $\begin{array}{l}0.519 * * * \\
(0.17)\end{array}$ & $\begin{array}{l}0.532^{* * * *} \\
(0.17)\end{array}$ & $\begin{array}{l}0.544^{* * *} \\
(0.17)\end{array}$ & & & \\
\hline $\begin{array}{l}\text { Dummy for the start } \\
\text { of Ramadhan } \\
\text { (alternative) }\end{array}$ & & & & $\begin{array}{l}1.121^{* * *} \\
(0.17)\end{array}$ & $\begin{array}{l}1.125^{* * *} \\
(0.18)\end{array}$ & $\begin{array}{l}1.159 * * * \\
(0.17)\end{array}$ \\
\hline $\begin{array}{l}\text { Dummy for the Eid UI } \\
\text { Fitr day (alternative) }\end{array}$ & & & & $\begin{array}{l}0.385^{* *} \\
(0.17)\end{array}$ & $\begin{array}{l}0.388^{* *} \\
(0.17)\end{array}$ & $\begin{array}{l}0.411^{* *} \\
(0.17)\end{array}$ \\
\hline $\begin{array}{l}\text { Percent increase in } \\
\text { minimum wage }\end{array}$ & & $\begin{array}{l}-0.001 \\
(0.00)\end{array}$ & $\begin{array}{l}-0.000 \\
(0.00)\end{array}$ & & $\begin{array}{l}-0.000 \\
(0.00)\end{array}$ & $\begin{array}{l}-0.000 \\
(0.00)\end{array}$ \\
\hline $\begin{array}{l}\text { Broad money (M2) } \\
\text { supply }\end{array}$ & & $\begin{array}{l}0.000 \\
(0.00)\end{array}$ & $\begin{array}{l}0.000 \\
(0.00)\end{array}$ & & $\begin{array}{l}0.000 \\
(0.00)\end{array}$ & $\begin{array}{l}0.000 \\
(0.00)\end{array}$ \\
\hline $\begin{array}{l}\text { IDR per US\$ } \\
\text { exchange rate }\end{array}$ & & $\begin{array}{l}0.000 \\
(0.00)\end{array}$ & $\begin{array}{l}0.000 \\
(0.00)\end{array}$ & & $\begin{array}{l}0.000 \\
(0.00)\end{array}$ & $\begin{array}{l}0.000 \\
(0.00)\end{array}$ \\
\hline $\begin{array}{l}\text { Percent change in } \\
\text { int'l food price }\end{array}$ & & $\begin{array}{l}-0.006 \\
(0.00)\end{array}$ & $\begin{array}{l}-0.005 \\
(0.00)\end{array}$ & & $\begin{array}{l}-0.006^{*} \\
(0.00)\end{array}$ & $\begin{array}{l}-0.005 \\
(0.00)\end{array}$ \\
\hline $\begin{array}{l}\text { Percent change in } \\
\text { int'l oil price }\end{array}$ & & $\begin{array}{l}0.007 \\
(0.01)\end{array}$ & $\begin{array}{l}0.006 \\
(0.01)\end{array}$ & & & \\
\hline $\begin{array}{l}\text { Dummy for gasoline } \\
\text { price increase }\end{array}$ & & & $\begin{array}{l}0.276 \\
(0.20)\end{array}$ & & & \\
\hline $\begin{array}{l}\text { Dummy for gasoline } \\
\text { price decrease }\end{array}$ & & & $\begin{array}{l}-0.276 \\
(0.41)\end{array}$ & & & \\
\hline $\begin{array}{l}\text { Dummy for gasoline } \\
\text { price increase } \\
\text { (alternative) }\end{array}$ & & & & & & $\begin{array}{l}0.444 * * \\
(0.20)\end{array}$ \\
\hline $\begin{array}{l}\text { Dummy for gasoline } \\
\text { price decrease } \\
\text { (alternative) }\end{array}$ & & & & & & $\begin{array}{l}-0.250 \\
(0.40)\end{array}$ \\
\hline Observations & 9,816 & 9,054 & 9,054 & 9,816 & 9,054 & 9,054 \\
\hline R-squared & 0.071 & 0.080 & 0.085 & 0.082 & 0.091 & 0.102 \\
\hline Number of dcode & 66 & 59 & 59 & 66 & 59 & 59 \\
\hline
\end{tabular}

Robust standard errors in parentheses

*** $p<0.01,{ }^{* *} p<0.05, * p<0.1$

\section{Result for The Relationship Ramadhan and Eid UI Fitr dummies elaborated on Inflation}

Furthermore, we shows the result with Ramadhan and Eid UI Fitr dummies elaborated. Ramadhan dummies elaborated in four parts, dummy for before the month of Ramadhan, dummy for the beginning of Ramadhan, dummy for the middle of Ramadhan, and dummy for the end of Ramadhan. While, Eid UI Fitr dummies elaborated in two parts, dummy for the Eid UI Fitr day and dummy for middle Eid UI Fitr day. Each part reflect one third of the month, as ten days in the beginning, middle and end of month. This elaboration was conducted to find out more in detail about inflation movements around the month of Ramadhan and Eid UI Fitr. 
Saleh, Wardani, \& Ivantri

Ramadhan, Eid UI Fitr, and Inflation: Lesson from Indonesian Subnational Data

Table 3 The Results with Ramadhan and Eid UI Fitr dummies elaborated

\begin{tabular}{|c|c|c|c|}
\hline \multirow[b]{2}{*}{ VARIABLES } & \multicolumn{3}{|c|}{ Pooled Least Squares (PLS) } \\
\hline & (1) & (2) & (3) \\
\hline & Inflation & Inflation & Inflation \\
\hline Dummy for before the month of Ramadhan & $\begin{array}{c}-0.241 * * * \\
(0.05)\end{array}$ & $\begin{array}{c}-0.296 * * * \\
(0.05)\end{array}$ & $\begin{array}{c}-0.383 * * * \\
(0.05)\end{array}$ \\
\hline Dummy for the beginning of Ramadhan & $\begin{array}{c}0.581 * * * \\
(0.06)\end{array}$ & $\begin{array}{c}0.592 * * * \\
(0.06)\end{array}$ & $\begin{array}{c}0.686 * * * \\
(0.06)\end{array}$ \\
\hline Dummy for the Middle of Ramadhan & $\begin{array}{c}0.274^{* * *} \\
(0.06)\end{array}$ & $\begin{array}{c}0.294^{* * *} \\
(0.06)\end{array}$ & $\begin{array}{c}0.300 * * * \\
(0.06)\end{array}$ \\
\hline Dummy for the End of Ramadhan & $\begin{array}{c}0.730 * * * \\
(0.06)\end{array}$ & $\begin{array}{c}0.717^{* * *} \\
(0.06)\end{array}$ & $\begin{array}{c}0.683 * * * \\
(0.06)\end{array}$ \\
\hline Dummy for the Eid UI Fitr day & $\begin{array}{c}-0.191 * * * \\
(0.06)\end{array}$ & $\begin{array}{c}-0.188 * * * \\
(0.06)\end{array}$ & $\begin{array}{c}-0.160 * * * \\
(0.06)\end{array}$ \\
\hline Dummy for middle Eid UI Fitr day & $\begin{array}{c}0.276 * * * \\
(0.05)\end{array}$ & $\begin{array}{c}0.285^{* * *} \\
(0.05)\end{array}$ & $\begin{array}{c}0.305^{* * *} \\
(0.05)\end{array}$ \\
\hline Percent increase in minimum wage & & $\begin{array}{l}-0.000 \\
(0.00)\end{array}$ & $\begin{array}{l}-0.000 \\
(0.00)\end{array}$ \\
\hline Broad money (M2) supply & & $\begin{array}{c}0.000 * * \\
(0.00)\end{array}$ & $\begin{array}{l}0.000 \\
(0.00)\end{array}$ \\
\hline IDR per US\$ exchange rate & & $\begin{array}{c}-0.000 * * * \\
(0.00)\end{array}$ & $\begin{array}{c}-0.000 * * * \\
(0.00)\end{array}$ \\
\hline Percent change in int'l food price & & $\begin{array}{c}-0.006^{* * *} \\
(0.00)\end{array}$ & $\begin{array}{c}-0.006 * * * \\
(0.00)\end{array}$ \\
\hline Percent change in int'l oil price & & $\begin{array}{c}0.008^{* * *} \\
(0.00)\end{array}$ & $\begin{array}{c}0.008 * * * \\
(0.00)\end{array}$ \\
\hline Dummy for gasoline price increase & & & $\begin{array}{c}0.506^{* * *} \\
(0.04)\end{array}$ \\
\hline Dummy for gasoline price decrease & & & $\begin{array}{l}-0.079 \\
(0.08)\end{array}$ \\
\hline Observations & 11,928 & 10,942 & 10,942 \\
\hline R-squared & 0.105 & 0.121 & 0.131 \\
\hline Standard errors in parentheses & & & \\
\hline$* * * p<0.01, * * p<0.05, * p<0.1$ & & & \\
\hline
\end{tabular}

In table 3, the coefficients each part of dummies for Ramadhan and for Eidul Fitr day are all significant at the 1 percent level. In terms of interpretation, using in column 3 , the coefficients from PLS estimator are $-0.383,0.686,0.300,0.683,-0.160,0.305$ for before the month of Ramadhan, the beginning of Ramadhan, the middle of Ramadhan, the end of Ramadhan, the Eid UI Fitr day and middle Eid UI Fitr day. We can see that the effect of dummy for before the month of Ramadhan on local inflation is negative and statistically significant. The magnitude of -0.383 indicates that local inflation rates in Indonesia will be 0.383 percent lower in the month before Ramadhan fall than in the months outside the events of Ramadhan. In addition, it was also found that the effect of dummy for the beginning of Ramadhan, dummy for the middle of Ramadhan, and dummy for the end of Ramadhan on inflation are all positive and statistically significant. The magnitude of 0.686 , $0.300,0.683$ implies that local inflation rates in Indonesia will be increase 0.686 percent 
in the beginning of Ramadhan, 0.300 percent in the middle of Ramadhan, and 0.683 percent in the end of Ramadhan. Then, we found that the beginning of Eid UI Fitr is a negative and statistically significant effect on local inflation. The magnitude of 0.16 indicates that local inflation rates in Indonesia will be 0.16 percent lower in the beginning of Eid UI Fitr than in the months outside the events of Eid UI Fitr. Finally, in the middle Eid $\mathrm{UI}$ Fitr is found to have a positive and statistically significant on local inflation. The magnitude of 0.365 indicates that local inflation rates in Indonesia will be 0.365 percent higher in the middle of Eid UI Fitr than in the months outside the events of Eid UI Fitr.

In more detail, the effect of Ramadhan and Eid UI Fitr on inflation have statistically significant with an interesting pattern. Before Ramadhan shows a negative influence on inflation and when Ramadhan fall it has a positive influence. Then, in the beginning of Eid UI Fitr shows negative effect, furthermore in the middle of Eid UI Fitr shows positive effect.

Before the fall of Ramadhan shows a negative influence, it cause the demand of Muslim community has not increased and the success of the government's anticipation. We well known that inflation in Ramadhan as a seasonal event which is always anticipated by the government of Indonesia. Anticipation by the government is usually in the form of maintaining the availability of goods and affordability of prices on the market. Technically, government efforts are carried out in several ways such as increasing monitoring and prevention of hoarding, ensuring the smoothness of supply chain operations, and market operations.

Then, during Ramadhan shows a positive influence on inflation, which is caused by an increase in the demand for Muslims. Theoretically, inflation can arise from the demand side when there is excess demand in the interaction between the demand and supply side of an economy (demand-pull inflation). The AC Nielsen study in Ramadhan showed sales of consumer goods in Indonesia rose 9.2 percent. Biscuit sales, for example, increased 11 times, canned fish and meat doubled, sausages and meatballs increased by 34 percent. It's in the modern market. In traditional markets there is also a high increase in demand (Utomo, 2016). Increased consumption of Muslims in the month of Ramadhan is a contradiction with the message of worship of Ramadhan and Islamic teachings. One central theme of Ramadhan is the control of desire, nafsu. Ramadhan is largely about learning to control desires such as hunger, sexual drive, emotions (Hellman, 2008) and intended to give the fasting person a deeper understanding of what it is to be poor and how the less fortunate suffer (Ahmed, 2001). In addition, Islamic teachings instruct humans not to over-consume (Quran 7:31).

Beyond the fasting that is central to Ramadhan, the entire month is a period of increased spirituality and religious contemplation for Muslims, specially on charity. Alongside the rituals of prayer and fasting, giving is a natural element of this auspicious month. As a result, during Ramadhan, much charitable giving is done by the prosperous community to the poor and less fortunate. This has an impact on increasing the purchasing power of low income communities, so will be increase of demand. 
In addition, the economic mechanism that is built in the system of state and society also allows the occurrence of Ramadhan inflation. The constitutive obligation to provide Tunjangan Hari Raya (THR) or Religious Holiday Allowances to the workforce and massive remittances from overseas workers have increased demand in the market and also the amount of money supply. The more money circulating as a result the lower the real value of money. Prices that have risen to the market mechanism become increasingly burdensome because the real value of money goes down.

This study also shows in the beginning Eid UI Fitr gave a negative influence on inflation and in the middle of the month had a positive influence. The negative impact was caused by a decrease in the demand of Muslim communities. We know that all the needs of Muslim communities at the beginning of Eid Al-Fitr have been prepared during the month of Ramadhan. Then in the middle of Eid UI Fitr, a positive impact arose because Muslims returned to normal activities and increased demand as a result of their return to urban areas.

As before, we comparing the results of a regression using PLS and PCSE estimator that our variable of interest namely Ramadhan and Eid UI Fitr, in all have the sign and significance remains unchange. For the result using PCSE see Appendix C.

\section{Conclusion}

This paper attempts to answer the question of whether Ramadhan and Eid UI Fitr can stimulate inflation. We are using a panel of 66 local economies in Indonesia for the period January 2000 and December 2017. Our main results can be summed up as follows. First, within PLS, we find that the effect of Ramadhan and Eid UI Fitr on local inflation is positive and statistically significant. Second, within FEM estimator, we find the same conclusion. The possible reasons for explaining the results is the high of public demand in the moment of Ramadhan and Eid UI Fitr. This is driven by the lack of Muslim awareness of the essence of fasting as a form of self-control. In fact, Muslims in general will spend more in Ramadhan and Eid UI Fitr. Furthermore, the drive for charity and religious holiday allowances in the month of Ramadhan and Eid al-Fitr is also a cause of increased aggregate demand. To enhance academic understanding of this subject, this research can be extended by employing mediating or moderating models in order to examine the conditions which Ramadhan and Eid UI Fitr could affect inflation. They can also examine the roles of Muslim population, religiosity, and law enforcement in advancing the relationship Islamic holy month and inflation. 


\section{Appendix}

Table 4 Details on the Variable Definitions and Sources

\begin{tabular}{|c|c|c|}
\hline Monthly local inflation rates & - & $\begin{array}{l}\text { Month-to-month percent change in the local consumer price } \\
\text { index. } \\
\text { Taken from the Statistics Indonesia's website of (BPS 2015). }\end{array}$ \\
\hline $\begin{array}{l}\text { Dummy for the start of Ramadhan } \\
\text { (basic designation) }\end{array}$ & - & $\begin{array}{l}\text { Binary variable given the value } 1 \text { for all the months with the first } \\
\text { day of Ramadhan and zero otherwise. } \\
\text { Constructed using data collected from the Ministry of Religious } \\
\text { Affairs' releases and media archives. }\end{array}$ \\
\hline $\begin{array}{l}\text { Dummy for the start of Ramadhan } \\
\text { (alternative designation) }\end{array}$ & - & $\begin{array}{l}\text { Binary variable comparable to the dummy for the start of } \\
\text { Ramadhan, but designated in an alternative way. Rather than } \\
\text { given the value } 1 \text { for all the months with the first day of } \\
\text { Ramadhan, it is valued } 1 \text { in the succeeding months if the first day } \\
\text { of Ramadhan took place within the final week. } \\
\text { Constructed using data collected from the Ministry of Religious } \\
\text { Affairs' releases and media archives. }\end{array}$ \\
\hline $\begin{array}{l}\text { Dummy for the day of Eid UI Fitr } \\
\text { (basic designation) }\end{array}$ & - & $\begin{array}{l}\text { Binary variable given the value } 1 \text { for all the months with the day } \\
\text { of Eid UI Fitr and zero otherwise. } \\
\text { Constructed using data collected from the Ministry of Religious } \\
\text { Affairs' releases and media archives. }\end{array}$ \\
\hline $\begin{array}{l}\text { Dummy for the day of Eid UI Fitr } \\
\text { (alternative designation) }\end{array}$ & - & $\begin{array}{l}\text { Binary variable comparable to the dummy for the day of Eid UI } \\
\text { Fitr, but designated in an alternative way. Rather than given the } \\
\text { value } 1 \text { for all the months with the day of Eid UI Fitr, it is valued } 1 \\
\text { in the succeeding months if the day of Eid UI Fitr took place } \\
\text { within the final week. } \\
\text { Constructed using data collected from the Ministry of Religious } \\
\text { Affairs' releases and media archives. }\end{array}$ \\
\hline \multirow[t]{2}{*}{ Percent increase in minimum wage } & - & The percentages of the changes in the local minimum wage. \\
\hline & - & $\begin{array}{l}\text { Calculated using data compiled from government decrees, } \\
\text { particularly the decrees of governors on local minimum wage } \\
\text { rates }\end{array}$ \\
\hline Broad money (M2) supply & - & $\begin{array}{l}\text { The sum of currency outside banks, demand deposits other than } \\
\text { those of the central government, and the time, savings, and } \\
\text { foreign currency deposits of resident sectors other than the } \\
\text { central government. } \\
\text { Taken from the central bank of Indonesia's website (Bank } \\
\text { Indonesia 2015). }\end{array}$ \\
\hline IDR per US\$ exchange rate & - & $\begin{array}{l}\text { The monthly average exchange rate of Indonesian Rupiah to } \\
\text { United States' dollar. } \\
\text { Taken from the central bank of Indonesia's website (Bank } \\
\text { Indonesia 2015). }\end{array}$ \\
\hline Percent change in int'l oil price & - & $\begin{array}{l}\text { The percentages of the changes in international oil prices. } \\
\text { Calculated using the monthly averages of the Europe Brent Spot } \\
\text { Prices (FOB) data published by the United States' Energy } \\
\text { Information Administration (EIA 2015). }\end{array}$ \\
\hline Percent change in int'l food price & - & $\begin{array}{l}\text { The percentages of the changes in international food prices. } \\
\text { Calculated using the monthly food price index data published by } \\
\text { the Food and Agriculture Organization (FAO 2015). }\end{array}$ \\
\hline $\begin{array}{l}\text { Dummy for gasoline price increase } \\
\text { (basic designation) }\end{array}$ & - & $\begin{array}{l}\text { Binary variable given the value } 1 \text { for all the months with a } \\
\text { gasoline price increase and } 0 \text { otherwise irrespective of when in } \\
\text { the month the gasoline price increase took place. } \\
\text { Constructed using information compiled from various } \\
\text { government and media archives. }\end{array}$ \\
\hline $\begin{array}{l}\text { Dummy for gasoline price increase } \\
\text { (alternative designation) }\end{array}$ & - & $\begin{array}{l}\text { Binary variable comparable to the dummy for gasoline price } \\
\text { increase, but designated in an alternative way. Rather than given } \\
\text { the value } 1 \text { for all the months with a gasoline price increase, it is } \\
\text { valued } 1 \text { in the succeeding months if the gasoline price increase } \\
\text { took place within the final week. } \\
\text { Constructed using information compiled from various } \\
\text { government and media archives. }\end{array}$ \\
\hline
\end{tabular}


Saleh, Wardani, \& Ivantri

Ramadhan, Eid UI Fitr, and Inflation: Lesson from Indonesian Subnational Data

\begin{tabular}{|c|c|}
\hline Monthly local inflation rates & $\begin{array}{l}\text { Month-to-month percent change in the local consumer price } \\
\text { index. } \\
\text { - Taken from the Statistics Indonesia's website of (BPS 2015). }\end{array}$ \\
\hline $\begin{array}{l}\text { Dummy for gasoline price decrease } \\
\text { (basic designation) }\end{array}$ & $\begin{array}{l}\text { - Binary variable given the value } 1 \text { for all the months with a } \\
\text { gasoline price decrease and } 0 \text { otherwise irrespective of when in } \\
\text { the month the gasoline price increase took place. } \\
\text { - Constructed using information compiled from various } \\
\text { government and media archives. }\end{array}$ \\
\hline $\begin{array}{l}\text { Dummy for gasoline price decrease } \\
\text { (alternative designation) }\end{array}$ & $\begin{array}{l}\text { - Binary variable comparable to the dummy for gasoline price } \\
\text { decrease, but designated in an alternative way. Rather than given } \\
\text { the value } 1 \text { for all the months with a gasoline price decrease, it is } \\
\text { valued } 1 \text { in the succeeding months if the gasoline price increase } \\
\text { took place within the final week. } \\
\text { - Constructed using information compiled from various } \\
\text { government and media archives. }\end{array}$ \\
\hline
\end{tabular}

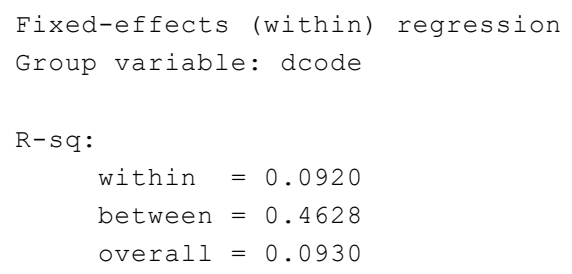

\begin{tabular}{|c|c|c|c|c|c|c|}
\hline inflation & Coef. & Std. Err. & t & $P>|t|$ & [95\% Conf. & Interval] \\
\hline ramadan 30 & 1.008421 & .0418488 & 24.10 & 0.000 & .9263878 & 1.090454 \\
\hline eidulfitr 30 & .5463502 & .0409529 & 13.34 & 0.000 & .4660731 & .6266272 \\
\hline oilprice & .006131 & .0011826 & 5.18 & 0.000 & .0038128 & .0084493 \\
\hline fpindex & -.004863 & .0008084 & -6.02 & 0.000 & -.0064476 & -.0032783 \\
\hline exchangerate & $7.54 e-06$ & .0000111 & 0.68 & 0.499 & -.0000143 & .0000294 \\
\hline pcminwage & -.000178 & .000714 & -0.25 & 0.803 & -.0015775 & .0012216 \\
\hline m2 & $2.18 e-07$ & $5.55 e-08$ & 3.94 & 0.000 & $1.10 e-07$ & $3.27 e-07$ \\
\hline gasopup30 & .3593344 & .0489387 & 7.34 & 0.000 & .2634034 & .4552654 \\
\hline gasopdn 30 & -.2244123 & .0903506 & -2.48 & 0.013 & -.4015201 & -.0473045 \\
\hline${ }_{-}$cons & .6009144 & .1058965 & 5.67 & 0.000 & .3933331 & .8084957 \\
\hline sigma_u & .05587186 & & & & & \\
\hline sigma_e & 1.0812216 & & & & & \\
\hline rho & .00266317 & (fraction & of varia & ce due & $\left.u_{-} i\right)$ & \\
\hline
\end{tabular}

Figure $1 \mathrm{~F}$ test or Chow test

The result of $F$ test is accepted null hypothesis ( $p$-value is $1.0000>0.05$ ), in other word $\mathrm{PLS}$ is more better than FE. 
Test: Ho: difference in coefficients not systematic

$$
\begin{aligned}
\operatorname{chi2}(8) & =(b-B) '\left[\left(V_{-} b-V_{-} B\right)^{\wedge}(-1)\right](b-B) \\
& =90.92 \\
\text { Prob }>\operatorname{chi} 2 & =0.0000
\end{aligned}
$$

Figure 2 Hausman Test

The result of Hausman test shows that $p$-value is $0.00<0.05$ (Ho = rejected) in other word Fixed Effect is appropriate than Random Effect.

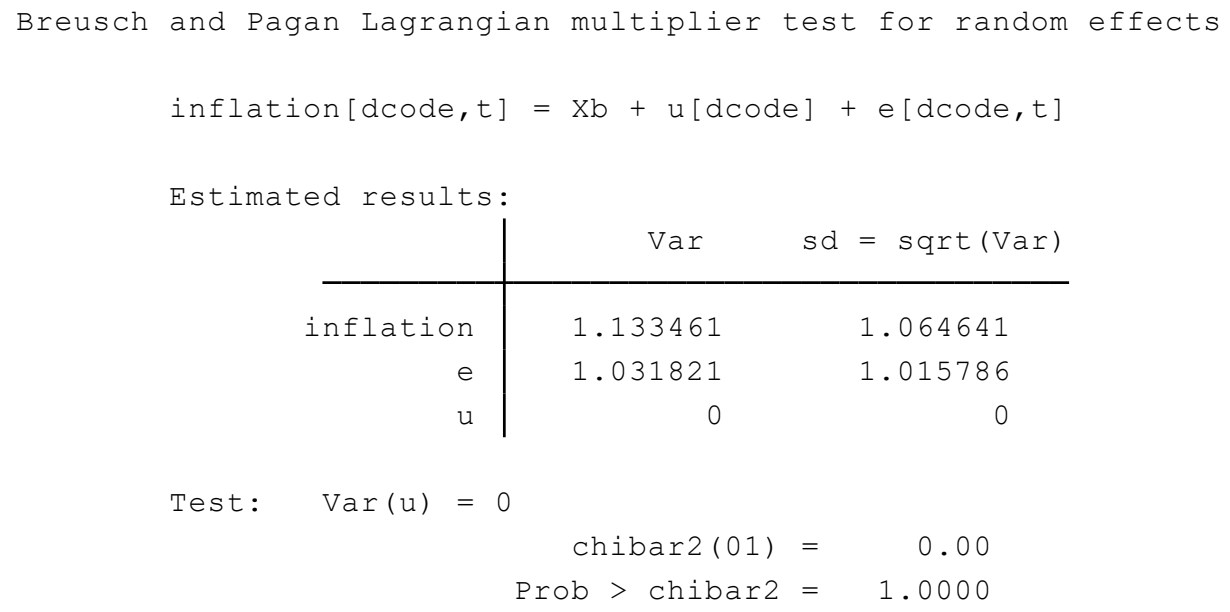

Figure 3 Lagrange Test

The result of $F$ test is accepted null hypothesis ( $p$-value is $1.0000>0.05$ ), in other word PLS is appropriate than RE.

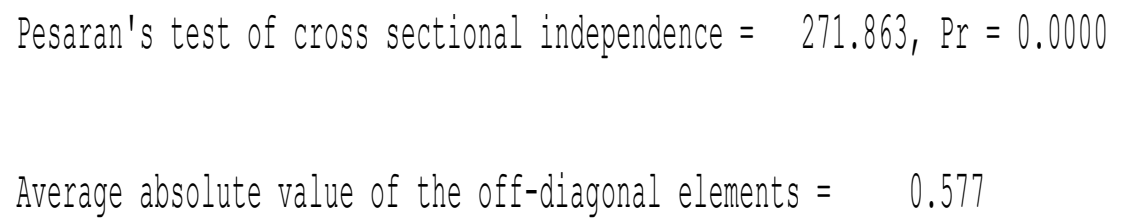

The result of Pesaran CD test is strongly rejects the null hypothesis of no cross-sectional dependence. 
Saleh, Wardani, \& Ivantri

Ramadhan, Eid UI Fitr, and Inflation: Lesson from Indonesian Subnational Data

Table 5 The Results with Ramadhan and Eid UI Fitr dummies elaborated

\begin{tabular}{|c|c|c|c|}
\hline \multirow[b]{2}{*}{ VARIABLES } & \multicolumn{3}{|c|}{ PCSE } \\
\hline & (1) & $(2)$ & (3) \\
\hline & Inflation & Inflation & Inflation \\
\hline \multirow[t]{2}{*}{ Dummy for before the month of Ramadhan } & -0.365 & $-0.401^{*}$ & $-0.477 * *$ \\
\hline & $(0.23)$ & $(0.24)$ & $(0.24)$ \\
\hline \multirow[t]{2}{*}{ Dummy for the beginning of Ramadhan } & $0.708 * *$ & $0.705^{* *}$ & $0.789 * * *$ \\
\hline & $(0.29)$ & $(0.30)$ & $(0.30)$ \\
\hline \multirow[t]{2}{*}{ Dummy for the Middle of Ramadhan } & 0.339 & 0.371 & 0.368 \\
\hline & $(0.31)$ & $(0.31)$ & $(0.31)$ \\
\hline \multirow[t]{2}{*}{ Dummy for the End of Ramadhan } & $0.731 * *$ & $0.738 * *$ & $0.721^{* *}$ \\
\hline & $(0.30)$ & $(0.31)$ & $(0.31)$ \\
\hline \multirow[t]{2}{*}{ Dummy for the Eid UI Fitr day } & -0.272 & -0.284 & -0.272 \\
\hline & $(0.29)$ & $(0.29)$ & $(0.29)$ \\
\hline \multirow[t]{2}{*}{ Dummy for middle Eid UI Fitr day } & 0.342 & 0.352 & 0.367 \\
\hline & $(0.24)$ & $(0.24)$ & $(0.24)$ \\
\hline \multirow[t]{2}{*}{ Percent increase in minimum wage } & & -0.001 & -0.000 \\
\hline & & $(0.00)$ & $(0.00)$ \\
\hline \multirow[t]{2}{*}{ Broad money (M2) supply } & & 0.000 & 0.000 \\
\hline & & $(0.00)$ & $(0.00)$ \\
\hline \multirow[t]{2}{*}{ IDR per US\$ exchange rate } & & 0.000 & 0.000 \\
\hline & & $(0.00)$ & $(0.00)$ \\
\hline \multirow[t]{2}{*}{ Percent change in int'l food price } & & $-0.006^{*}$ & -0.005 \\
\hline & & $(0.00)$ & $(0.00)$ \\
\hline \multirow[t]{2}{*}{ Percent change in int'l oil price } & & 0.008 & 0.007 \\
\hline & & $(0.01)$ & $(0.01)$ \\
\hline \multirow[t]{2}{*}{ Dummy for gasoline price increase } & & & $0.366^{*}$ \\
\hline & & & $(0.21)$ \\
\hline \multirow[t]{2}{*}{ Dummy for gasoline price decrease } & & & -0.269 \\
\hline & & & $(0.41)$ \\
\hline Observations & 9,816 & 9,054 & 9,054 \\
\hline R-squared & 0.114 & 0.125 & 0.132 \\
\hline Number of dcode & 66 & 59 & 59 \\
\hline
\end{tabular}

Standard errors in parentheses

*** $p<0.01, * * p<0.05, * p<0.1$

\section{References}

Ahmed, A. S. (2001). Islam Today: A Short Introduction to The Muslim World. London: Tauris Baltagi, B. H. (2005). Econometrics Analysis of Panel Data (3rd ed.). Chichester, England: John Wiley \& Sons Inc

Barro, R. J. (1995). Inflation and Economic Growth. Bank of England Quarterly Bulletin Q2, (1), 166-176. Retrieved from https://www.bankofengland.co.uk/quarterlybulletin/1995/q2/inflation-and-economic-growth

Bittencourt, M. (2012). Inflation and Economic Growth in Latin America: Some Panel Time-series Evidence. Economic Modelling, 29(2), 333-340. https://doi.org/10.1016/i.econmod.2011.10.018

Crabtree, S. (2010). Religiosity Highest in World's Poorest Nations. Retrieved November 19, 2018, Retrieved from https://news.gallup.com/poll/142727/religiosity-highestworld-poorest-nations.aspx 
De Hoyos, R. E., \& Sarafidis, V. (2006). Testing for Cross-Sectional Dependence in PanelData Models, The Stata Journal: Promoting communications on statistics and Stata, 6(4), 482-496. https://doi.org/10.1177\%2F1536867X0600600403

FAO. (2010). Strengthening Potato Value Chains: Technical and Policy Options for Developing Countries. The Food and Agriculture Organization of the United Nations and the Common Fund for Commodities.

Fuhrer, J., Kodrzycki, Y. K., Little, J. S., Olivei, G. P., \& Samuelson, P. A. (2009). Understanding Inflation and the Implications For Monetary Policy: A Phillips Curve Retrospective. London: The MIT Press.

Gali, J., \& Gertler, M. (1999). Infation Dynamics: A Structural Econometric Analysis. Journal of Monetary Economics, 44, 195-222. https://doi.org/10.1016/s0304-3932(99)00023-9

Goretti, M. (2008). Wage-Price Setting in New EU Member States (No. WP/08/243). Washington. https://doi.org/10.5089/9781451871012.001

Gregorio, J. De. (1992). The Effects of Inflation on Economic Growth Lessons from Latin America. European Economic Review, 36, 417-425. https://doi.org/10.1016/00142921(92)90098-h

Grigorian, D. A., \& Kock, U. (2010). Inflation and Conflict in Iraq : The Economics of Shortages Revisited. IMF Working Paper Middle.

Hellman, J. (2008). The Significance of Eating During Ramadan : Consumption and Exchange of Food in a Village in West Java. Food and Foodways: Explorations in the History and Culture of Human Nourishment, 16(3), 2001-2226. https://doi.org/10.1080/07409710802304176

Holland, A. S. (1984). The Impact of Inflation Uncertainty on the Labor Market. Federal Reserve Bank of ST. Louis, (August/September), 21-28.

Holz, C. A., \& Mehrotra, A. (2013). Wage and Price Dynamics in a Large Emerging Economy : The Case of China.

Huizinga, J. (1993). Inflation Uncertainty, Relative Price Uncertainty, and Investment in U.S Manufacturing. Journal of Money, Credit and Banking, 25(3), 521-549. Retrieved from https://www.jstor.org/stable/2077721

Hung, F.-S. (2003). Inflation, Financial Development, and Economic Growth. International Review of Economics \& Finance, 12(1), 45-67. https://doi.org/10.1016/s1059$\underline{0560(02) 00109-0}$

Kaihatsu, S., \& Nakajima, J. (2018). Has Trend Inflation Shifted?: An Empirical Analysis With an Equally-Spaced Regime-Switching Model. Economic Analysis and Policy, 59, 6983. https://doi.org/10.1016/i.eap. 2018.04.003

Laidler, D., \& Parkin, M. (1975). Inflation: A survey. The Economic Journal, 85(340), 741-809. https://doi.org/10.2307/2230624

Mills, G. T. (1996). The Impact of Inflation on Capital Budgeting and Working Capital. Journal Of Financial and Strategic Decisions, 9(1), 79-87.

Montes, G. C., \& da Cunha Lima, L. L. (2018). Effects of Fiscal Transparency on Inflation and Inflation Expectations: Empirical Evidence from Developed and Developing Countries. The Quarterly Review of Economics and Finance, 70, 26-37. https://doi.org/10.1016/i.qref.2018.06.002

Nickell, S., \& Quintini, G. (2003). Nominal Wage Rigidity and the Rate of Inflation. The Economic Journal, 113(490), 762-781. Retrieved from https://www.jstor.org/stable/3590282

Orphanides, A. (2002). Monetary-Policy Rules and the Great Inflation. American Economic Review, 92(2), 115-120. https://doi.org/10.1257/000282802320189104

Perrier, P., \& Amano, R. (2000). Credibility and Monetary Policy. Bank of Canada Review, 2000 (Spring), 11-17. https://doi.org/10.2139/ssrn.2962259 
Pesaran, M. H., (2004). General Diagnostic Tests for Cross Section Dependence in Panels. Center for Economic Studies and Ifo Institute (CESifo) Working Paper No. 1229.

Pesaran, M., (2007). A Simple Panel Unit Root Test in the Presence of Cross Section Dependence. Journal of Applied Econometrics, 22(2), 265-312. https://doi.org/10.1002/jae.951

Saad-Filho, A. 2000. Inflation theory: A critical literature review and a new research agenda, in Paul Zarembka (ed.) Value, Capitalist Dynamics and Money (Research in Political Economy, Volume 18) Emerald Group Publishing Limited, pp.335 - 362

The World Bank. (2013). Indonesia economic quarterly: Continuing adjustment. Retrieved from www.worldbank.org/id

Utomo, A. P. (2016). Ekonomi Ramadhan dan Lebaran | Republika Online. Retrieved October 30, 2018, Retrieved from https://republika.co.id/berita/koran/opinikoran/16/06/20/09264623-ekonomi-ramadhan-dan-lebaran

Vinayagathasan, T. (2013). Inflation and Economic Growth: A dynamic Panel Threshold Analysis for Asian Economies. Journal of Asian Economics, 26, 31-41. https://doi.org/10.1016/j.asieco.2013.04.001

Xu, Y., Chang, H.-L., Lobonţ, O.-R., \& Su, C.-W. (2016). Modeling Heterogeneous Inflation Expectations: Empirical Evidence from Demographic Data? Economic Modelling, 57, 153-163. https://doi.org/10.1016/i.econmod.2016.04.017 